duction of this cloudiness, in solutions of arsenious acid, has frequently been noticed. I am not aware that any attempthas been made to account for it. I have satisfied myself that it arises from the presence of arsenic acid, produced in these solutions, as I have already explained, by exposure to the air. The arseniate of silver, in its ordinary form, no doubt is of a deep-brown or red; but the colour varies greatly with the state of dilution of the fluid: when concentrated it is of a reddish-brown; when more dilute, brick-red; when still more dilute, greyish; and when extremely dilute, as $\frac{1}{1000}$, a whitish cloud, exactly similar to that which is observed in solutions of arsenious acid, after they are kept for some time.

Postscript.-1. - In Reinsch's process, if the arsenious acid exceeds one-fiftieth of a grain to one square inch of copper surface, the arsenical deposit is apt to peel cff, and, when the fluid is muddy, may be lost, unless the process is closely watched.

The scales thus detached do not consist exclusively of metallic arsenic; they contain a large proportion of metallic copper. This proportion I have never found less than sixty* five per cent; sometimes it is considerably greater.

2 . When these scales are heated in a test tube, a considerable quantity of arsenious acid sublimes in the usual crystalline form, but there is always a large residue unsublimed, consisting chiefly of oxide of copper, but containing also about one-half of the arsenic, apparently in the state of sub-arseniate of copper, with slight traces of sub-arsenite. The presence of the arsenic acid in the residuum may be easily shown by boiling it with solution of carbonate of potash, filtering, neutralizing it accurately with nitric acid, and then adding solntion of nitrate of silver, which gives a precipitate of red arseniate of silver.

3. A similar result is obtained when copper-foil coated with arsenic is heated in a test tube over a lamp. One-half only of the arsenic sublimes in the state of arsenious acid. The other half remains as in the preceding experiment, in the state of sub-arseniate of copper, chiefly adhering to the copper-foil, but partly in the form of a white stain on the glass, near the bottom of the tube. The arsenic acid may be obtained, both from the copper-foil and from the white stain, in the state of arseniate of silver, by the process above described.

When it is wished to obtain the arsenic in the form of sulphuret, the alkaline solution, after boiling with the copper, should be saturated with sulphurous acid gas, to convert the arsenic acid into the arsenious. Muriatic acid should then be added in great excess, and the superfuous sulphurous acid disengaged by boiling. When this is effected, a current of sulphuretted hydrogen, being passed through the fluid, will precipitate the arsenic in the state of orpiment.

\section{CASE OF VARIOLA COTEMPORANEOUS WITH VACCINIA, BOTH MODIFIED.}

B Y ROBERT FOWLER, M.D. Edin.

RESIDENT MEDICAL OHFICER TO THE LOUGHBOROUGH DISPENSARY

ON March 31 st last I vaccinated Marianne W-_, aged three years, a perfectly healthy child. When next seen, on April 7th, I was told that on the very day (April 1st) following vaccination she became very sick, vomiting frequently, and feverish. On the evening of the next day (April 2nd) the mother fancies that there was a little redness about the chin, which however on the 3rd April assumed the aspect of decided papulæ over the whole face, arms, legs, and body. I now ascertained that at the school to which the child had gone up to the day of its being taken ill two or three of the scholars had had the small-pox about a month ago, and had returned among the other children some few days back.

April 7th.-The vaccine vesicles (seventh day) are larger than the variolous, very little elevated above the cuticle, irregular in shape, being not perfectly circular, but flattened and indented, and lobulated at the edges. There is evidently very little fluid in them, and no appearance of areola. The whole body is marked with distinct variolous vesicles, (fifth day,) having the same flattened aspect as, but smaller than, the vaccinia; and being so little elevated above the surface, they do not present that "shotty" feel so characteristic of variola, especially in its papular stage. Febrile action slight.

9th.--The variolous eruption (seventh day) is more turgid; that on the face is pustular, and a few of the pustules are beginning to scab; that on the arms is hemispheroidal, prominent, and pustular; that on the legs is opaque, but not distinctly pustular; the central depression still existing in some of the vesicles. The vaccinia (ninth day) is not more elevated, though the fluid seems more opaque; the vesicles are now about half an inch in diameter, but still present that irregular, indented appearance round their margin, external to which there is now an areola of about one line in diameter, as there is also around each variolous pustule. The variolous vesicles in the immediate neighbourhood of the vaccinia are much smaller and less opaque than elsewhere, neither are they so turgid or spherical as in other parts of the body. The mother attributes this to the child always lying on that side, (the right,) and certainly the left arm (which, how ever, by some oversight was not vaccinated) presents well-filled vesicles; the eruption of the right leg also is somewhat less prominent than that on the left, though certainly there is not that marked difference observable in the vesicles of the two arms.

10th.-Variolous eruption (eighth day) entirely pustular, scabbing going on in the face. Areola of vaccine vesicles (tenth day) no larger, though the vesicles themselves are larger, and beginning to lose their indented margin. The variolous eruption around vaccinia is now pnstular.

12th.-Scabbing progressing on the face, (tenth day,) and the pustules on the arms shrivelling up; no secondary fever. A scab perceptible ( $t$ welfth day) on each vaccine vesicle; no in. crease of areola, nor is there any surrounding induration.

14th.-Some of the pustules on the legs shrivelling, (twelfth day,) Vaccinia (fourteenth day) scabbing, the scabs being rather conical, and of a dirty light brown in colour; no increase of areola.

16th.-All the pustules of the legs shrivelling, (fourteenth day.) Scabs of vaccine vesicles (sixteenth day have fallen off, leaving an irregularly circular, purple-red mark, larger, though otherwise similar, to the stains of the variolous eruption; the vaccine stains are perfectly flat and smooth, without the slightest indication of the small depressions and radiating lines characteristic of a good vaccine cicatrix.

19th.-The whole body presents purple-red stains.

Remarks. - Considering vaccinia as a disease sui generis, we have here two exanthemata co-existing in one person, and each by its presence modifying, but not superseding, the regular course of the other. That the vaccinia was modified, is shown by the irregular shape and flattened condition of the vesicles, by the absence of the areola and surrounding hardness, by the shape and colour of the scab, by the duration of the eruption-the scab having fallen off on the sixteenth instead of about the twentieth day - and by the character of the remaining cicatrix. The size of the pustules and the absence of the secondary fever, notwithstanding the duration of the eruption was not considerably shortened, indicate that the variola was of a modified kind. By those sceptical of the prophylaxis of vaccination, the above case will be greedily seized on; but are we not from past experience warranted in surmising, and even affirming, that, although the discovery of Jenner was in this case incapable of arresting or superseding the progress of the poison already concocting in the blood, yet that to the co-existence of the vaccine virus this child owes the safety and mildness of its attack?

May, 1852

\section{eat firror}

OF THE PRACTICE OF

\section{MEDICINE AND SURGERY IN THE \\ HOSPITALS OF LONDON.}

Nulla est alia pro certo noscendi via, nisi quam plurimas et morborum, et dissectionum historias, tum aliorum proprias, coliectas habere et inter se comparare.-Morgagni. De Sed. et Caus. Morb., lib. 14. Proomium.

\section{KING'S COLLEGE HOSPITAL.}

\section{Simple Sarcomatous Tumour in the Axilla; Spontaneous}

Cure by Disintegration.

(Under the care of Mr. FERGusson.)

Scrofoxous enlargement of lymphatic glands is an affection, as every one knows, very frequently met with among the illfed, ill-clothed, and ill housed children of our labouring classes; and it is interesting to observe how rapidly the heaith of such children improves, by very simple treatment, when they are admitted into any of our charitable institutions, where regular habits, good diet, and cleanliness perform wonders, provided the sap circulating in their little frames is not of too unhealthy an origin. Cases of this nature it would 